\title{
Pengakuan Hak Atas Tanah Adat dalam Pemberian Ganti Kerugian pada Pembebasan Tanah untuk Kepentingan Umum di Kota Kendari
}

\author{
Recognition of Customary Land Rights in Providing Compensation for Land \\ Acquisition for Public Interest in Kendari City
}

\author{
Guswan Hakim \\ Fakultas Hukum Universitas Halu Oleo Kendari \\ E-mail: guswan_hakim@yahoo.com \\ Siti Misnar Abdul Jalil \\ Fakultas Hukum Universitas Lakidende \\ E-mail: sitimisnar@yahoo.co.id
}

\begin{abstract}
This research aims to determine the respect/position of customary land rights in the provision of compensation for land acquisition for public purposes in the city of Kendari. The research method used in this research is normative research using empirical data assistance, namely data/information on the implementation of land acquisition for the benefit of the Kendari Outer Ring Road project. The results of the study note that the implementation of land acquisition in the public interest by prioritizing the principles of humanity, democracy and justice, can be found in several Presidential Decrees and amendments as follows: Decree of Presidential Regulation No. 36/2005 concerning Land Procurement for Implementation of Development in the Public Interest, which took effect on 5 June 2006, changed the provisions of Article 3 paragraph (1) of Presidential Regulation Number 36 of 2005, to become a new Article 3 stating that: "Relinquishment or surrender of land rights is carried out based on the principle of respect for land rights." The principle of respect for land rights is implicitly regulated in Article 1 letter $b$ of the Republic of Indonesia Presidential Regulation No. 71/2012 concerning the Provision of Land Procurement for Development in the Public Interest that land acquisition is an activity of providing land by providing appropriate and fair compensation to the rightful parties. The position of customary land in the acquisition of land for public use in the city of Kendari is carried out by way of consensus agreement with customary landowners about the amount of compensation received by customary landowners, the same is done by the land acquisition committee in the public interest of the lands that already have certificate of ownership of land. Respect for customary land is also reflected in the determination and award of compensation to customary
\end{abstract}


landowners, namely the difference in the value of compensation given to owners of land rights is not based on differences in land rights but rather on differences in the area of land acquired.

Keyword: recognition of customary land; compensation payment; land acquisition; public interest

\begin{abstract}
Abstrak: Penelitian ini bertujuan untuk mengetahui penghormatan/kedudukan terhadap hak atas tanah adat dalam pemberian ganti kerugian pada pembebasan tanah untuk kepentingan umum di Kota Kendari. Metode penelitian yang digunakan dalam penelitian ini adalah penelitian normatif dengan menggunakan bantuan data empiris yaitu data/informasi pelaksanaan pembebasan tanah untuk kepentingan proyek jalan lingkar luar Kota Kendari. Hasil dari penelitian diketahui bahwa Implementasi pengadaannya tanah untuk kepentingan umum dengan mengedepankan prinsip kemanusiaan, demokratis, dan adil, dapat ditemukan dalam beberapa Keputusan Presiden maupun perubahannya, yaitu: Keputusan Peraturan Presiden Nomor 36 tahun 2005 tentang Pengadaan Tanah Bagi Pelaksanaan Pembangunan Untuk Kepentingan Umum, yang mulai diberlakukan tanggal 5 Juni 2006 mengubah ketentuan Pasal 3 ayat (1) Peraturan Presiden Nomor 36 Tahun 2005, menjadi Pasal 3 baru yang berbunyi "Pelepasan atau penyerahan hak atas tanah dilakukan berdasarkan prinsip penghormatan terhadap hak atas tanah." Prinsip penghormatan terhadap hak atas tanah secara tersirat diatur dalam Pasal 1 huruf b Peraturan Presiden Republik Indonesia Nomor 71 Tahun 2012 Tentang Penyelenggaraan Pengadaan Tanah Bagi Pembangunan Untuk Kepentingan Umum bahwa pengadaan tanah adalah kegiatan menyediakan tanah dengan cara memberi ganti kerugian yang layak dan adil kepada pihak yang berhak. Kedudukan tanah adat dalam pengadaan tanah untuk kepentingan umum di Kota Kendari dilaksanakan dengan cara musyawarah mufakat dengan pemilik tanah adat tentang besarnya ganti rugi yang diterima para pemilik tanah adat, hal yang sama dilakukan oleh panitia pembebasan tanah untuk kepentingan umum terhadap tanah-tanah yang sudah memiliki sertifikat hak milik atas tanah. Penghormatan terhadap tanah adat tercermin juga dalam penetapan dan pemberian ganti rugi terhadap pemilik tanah adat yaitu Perbedaan nilai ganti rugi yang diberikan kepada pemilik hak atas tanah bukan didasarkan kepada perbedaan hak atas tanah tetapi lebih pada perbedaan luas tanah yang dibebaskan.
\end{abstract}

Kata kunci: pengakuan tanah adat; pemberian ganti kerugian; pembebasan tanah; kepentingan umum

\title{
PENDAHULUAN
}

Tanah adat adalah tanah yang dimiliki menurut hukum adat oleh individu atau Masyarakat hukum adat yang diakui baik subyek hukumnya maupun hak-haknya dalam pasal $18 \mathrm{~B}$ Undang-undang Dasar 1945. Kota Kendari dari aspek sejarah adalah merupakan wilayah sekaligus menjadi ibukota eks Kerajaan Laiwoi/Konawe dengan status swapraja Laiwoi dalam Afdeling Boeton en Laiwoi. Selain sebagai eks wilayah/ibu kota kerajaan Laiwoi/Konawe Kota Kendari (Kandai penamaan pada saat itu) adalah merupakan tempat 
tinggal masyarakat hukum adat Tolaki Konawe. Sebagai tempat pemukiman yang telah ada sebelum Indonesia merdeka maka hak atas tanah adat akan selalu dihormati sekaligus dilindungi sebelum hak itu dialihkan menurut Hukum.

Perkembangan selanjutnya Kota Kendari (Kandai) berdasarkan Perpu No. 2 Tahun 1964 tentang pembentukan Provinsi Sulawesi Tenggara, Kandai atau Kendari di tetapkan menjadi ibu Kota Provinsi Sulawesi Tenggara. Sebagai Ibu Kota Provinsi maka kebutuhan tanah untuk melakukan pembangunan sarana prasarana pemerintahan serta pelayanan masyarakat sangat diperlukan, kebutuhan tersebut semakin meningkat seiring perkembangan Kota Kendari serta pertambahan jumlah penduduk setelah era Reformasi.

Sebagai kota yang berkedudukan pada eks ibukota Kerajaan dan wilayah masyarakat hukum adat Tolaki Konawe maka kebutuhan tanah untuk pembangunan sering mengalami kendala karena adanya hak milik atau hak masyarakat hukum adat baik individu maupun ulayat terhadap tanah yang menjadi obyek pembangunan kantor atau infrastruktur pemerintahan.

Guna mengatasi kendala tersebut di atas, kebutuhan tanah oleh pemerintah Kota Kendari untuk pembangunan infrastruktur seperti jalan, maka ditempuh dengan cara melakukan pembebasan hak-hak atas tanah yang dilalui atau terkena proyek infrastruktur tersebut. sebagai dasar hukum yang dapat digunakan untuk melakukan pembebasan hak atas tanah yang dimiliki oleh warga Masyarakat adalah Pasal 33 ayat (3) Undang-Undang Dasar 1945 yang menyatakan bahwa: "Bumi, air dan kekayaan alam yang terkandung di dalamnya dikuasai oleh negara dan dipergunakan untuk sebesar-besarnya kemakmuran rakyat", maka lahirlah Undang-undang Nomor 5 Tahun 1960 tentang Peraturan Dasar Pokok-Pokok Agraria yang lebih dikenal dengan sebutan Undang-undang Pokok Agraria (disingkat UUPA). Dalam Pasal 2 ayat (1) Undang-undang Pokok Agraria ini disebutkan bahwa: "Bumi, air dan ruang angkasa termasuk kekayaan alam di dalamnya pada tingkat yang tertinggi dikuasai oleh negara sebagai organisasi kekuasaan seluruh rakyat".

Hak menguasai negara atas tanah dimaksudkan bahwa negara berhak pula untuk ikut campur tangan dalam pengertian bahwa setiap pemilik/pemegang Hak Atas Tanah tidaklah terlepas dari hak menguasai negara tersebut karena kepentingan umum adalah di atas kepentingan individu atau kepentingan kelompok. Namun demikian tidaklah berarti bahwa kepentingan individu atau kelompok itu dapat dikorbankan begitu saja dengan dalih kepentingan umum. Oleh karena itu, dalam Pelaksanaan Pembangunan Untuk Kepentingan Umum, isu yang sering mencuat adalah mengenai persoalan ganti 
kerugian dan penerapan upaya Konsinyasi yang dianggap melanggar Hak Asasi Manusia. Pasal 1 ayat 6 Undang-Undang Nomor 2 Tahun 2012 Pengadaan tanah bagi pembangunan untuk kepentingan umum bahwa Pelepasan Hak dari Pihak yang Berhak dilakukan dengan Ganti Kerugian yaitu penggantian yang layak dan adil kepada Pihak yang berhak dalam proses Pengadaan Tanah. untuk melaksanakan amanah undang-undang tersebut melalui Peraturan Presiden Nomor 71 Tahun 2012 tentang Penyelenggaraan Pengadaan Tanah Bagi Pembangunan Untuk Kepentingan Umum sebagaimana telah beberapa kali diubah terakhir dengan Peraturan Presiden Nomor 148 Tahun 2015 tentang Perubahan Keempat Atas Peraturan Presiden Nomor 71 Tahun 2012 tentang Penyelenggaraan Pengadaan Tanah bagi Pembangunan untuk Kepentingan Umum (Lembaran Negara Republik Indonesia Tahun 2015 Nomor 366); dan yang terakhir adalah Peraturan Presiden Republik Indonesia Nomor 102 Tahun 2016 Tentang Pendanaan Pengadaan Tanah Bagi Pembangunan untuk Kepentingan Umum dalam Rangka Pelaksanaan Proyek Strategis Nasional, menyatakan bahwa bentuk ganti kerugian yang dilakukan oleh pemerintah dengan memperhatikan jika untuk pengadaan tanah tersebut telah disetujui oleh $75 \%$ warga masyarakat, atau telah dibayarkan ganti kerugiannya sekitar 75\% kepada warga masyarakat, untuk melepaskan Hak Atas Tanah yang terkena lokasi pembangunan dimaksud, maka untuk sisanya yang masih belum mau melepaskan hak atas tanahnya dapat dilakukan upaya Konsinyasi berupa sejumlah uang yang dititipkan di Pengadilan Negeri setempat apabila tidak tercapainya kesepakatan mengenai bentuk maupun jumlah ganti kerugiannya dengan pemilik/pemegang Hak Atas Tanah. Namun jika warga masyarakat yang setuju untuk melepaskan Hak Atas Tanah kurang dari 50\%, maka pengadaan tanah dapat ditempuh melalui dua cara, yaitu: pertama, lokasi pembangunan tersebut dipindahkan ke tempat lain, atau jika tidak dapat dipindahkan ke tempat lain; maka kedua, dilakukan Pencabutan Hak Atas Tanah.

Secara garis besar pelaksanaan pengadaan tanah bagi pelaksanaan pembangunan untuk kepentingan umum meliputi beberapa tahapan, yaitu: ${ }^{1}$

1. Tahap pertama berupa pelaksanaan penyuluhan akan dilaksanakannya pengadaan tanah untuk pembangunan;

2. Tahap inventarisasi;

1 Agus Oprasi, Pelaksanaan Pemberian Ganti Kerugian Terhadap Hak Atas Tanah Yang Terkena Proyek Pembangunan Water Front City di Kabupaten Sambas, Provinsi Kalimantan Barat, Tesis, Semarang: Universitas Diponegoro, 2009, hlm. 2. 
3. Tahap pengumuman hasil inventarisasi;

4. Tahap penaksiran dan pengusulan besaran ganti kerugian berdasarkan penetapan Tim Penilai Harga Tanah;

5. Tahap pelaksanaan musyawarah. Dalam tahap ini apabila tidak tercapai kata sepakat, maka ditempuh upaya Konsinyasi dan Pencabutan Hak Atas Tanah. Sedangkan dalam hal tercapainya kesepakatan, maka tahap selanjutnya adalah pelaksanaan pembayaran ganti kerugian yang kemudian ditindaklanjuti dengan pembuatan Berita Acara Pelepasan Hak atau Penyerahan Hak Atas Tanah tersebut.

Pengaturan pembebasan tanah untuk kepentingan umum tersebut di atas hanya terhadap hak tanah yang dimaksud dalam Undang-Undang Nomor 5 Tahun 1960 tentang Peraturan Dasar Pokok-Pokok Agraria dan hak lain yang akan ditetapkan dengan undangundang-tanah. ${ }^{2}$ Undang-undang Tanah hingga saat ini belum diadakan sedangkan hak-hak tanah yang terdapat dalam Undang-Undang Pokok Agraria Nomor 5 tahun 1960 selanjutnya disingkat UUPA. Disebutkan: Hak milik, hak guna usaha, hak guna bangunan, hak pakai dan hak pengelolaan

Tanah adat sebagai hak masyarakat adat baik sebagai paguyuban/komunal maupun individu bukan merupakan obyek hak tanah yang harus di ganti rugi melalui pengadaan tanah untuk kepentingan umum, berdasarkan hal tersebut saya tertarik untuk melakukan penelitian tentang "Pengakuan Hak Atas Tanah Adat dalam Pemberian Ganti Kerugian dalam Pembebasan Tanah untuk Kepentingan Umum di Kota Kendari".

\section{METODE PENELITIAN}

Jenis penelitian/pendekatan yang digunakan oleh penulis adalah penelitian hukum normative empirik. Penelitian hukum normative menurut Peter Mahmud Marzuki ${ }^{3}$ yaitu penelitian hukum yang dilakukan dengan pendekatan undang-undang (statute approach), pendekatan kasus (case approach), pendekatan historis (historical approach), pendekatan komparatif (comparative approach), dan pendekatan konseptual (conceptual approach). Sedangkan normative empiris, ${ }^{4}$ yakni penelitian yuridis dilakukan dengan cara meneliti bahan pustaka yang merupakan data sekunder dan juga disebut penelitian kepustakaan.

\footnotetext{
2 Pasal 1 ayat 5 Undang-Undang Republik Indonesia Nomor 2 Tahun 2012 Tentang Pengadaan Tanah Bagi Pembangunan Untuk Kepentingan Umum.

3 Peter Mahmud Marzuki, Penelitian Hukum, Jakarta: Kencana Prenada Media Group, 2005, hlm. 93.

4 Ronny Hanitijo Soemitro, Metode Penelitian Hukum dan Jurimetri, Jakarta: Ghalia Indonesia, 1990, hlm. 36.
} 
Penelitian hukum empiris dilakukan dengan cara meneliti di lapangan yang merupakan data primer.

\section{ANALISIS DAN PEMBAHASAN}

\section{Pelaksanaan Pembebasan Tanah untuk Kepentingan Umum di Kota Kendari dan} Penghormatan/Pengakuan Hak Atas Tanah Adat

Proyek Pembangunan Jalan baru lingkar luar kota oleh Pemerintah Kota Kendari dimaksudkan akan menunjang sektor transportasi dengan daerah-daerah lainnya sehingga tidak terjadi kemacetan jalan-jalan dalam kota. Pembangunan Jalan lingkar luar erat kaitannya dengan sektor ekonomi, karena berdasarkan Rencana Umum Tata Ruang Wilayah Kota Kendari jalan tersebut merupakan akses terdekat dari bandara bagi lalulintas tenaga kerja asing dan sebaliknya merupakan jalan utama bagi muatan kontainer dari pelabuhan Bungkutoko maupun sebaliknya. sehingga dari aktivitas tersebut secara tidak langsung akan meningkatkan perekonomian masyarakat sekitar.

Proyek Pembangunan Jalan baru lingkar luar kota dimulai dari gerbang Puuwatu melintasi Kelurahan Abeli Dalam, Gerbang Perbatasan Baruga-Brimob, Nanga-nangaKantor Camat Abeli hingga Pelabuhan Bungkutoko memiliki panjang kurang lebih sepanjang 40 kilometer $(\mathrm{km})$ dengan lebar 30 sampai 40 meter.

Sejak dicanangkan proyek ini tahun 2014 diketahui terdapat 260 orang pemilik/pemegang Hak Atas Tanah 60 orang di antaranya yang dapat membuktikan tanahnya sebagai pemegang sertifikat hak milik sedangkan 200 orang tidak memiliki sertifikat hak milik dan perolehan hak atas tanah berdasarkan perolehan secara turun temurun ditandai adanya pohon kelapa dan kuburan Nenek moyang mereka di lokasi itu. ${ }^{5}$ Sebanyak 260 orang tersebut yang diupayakan untuk mendapatkan ganti kerugian atas pembebasan/pelepasan Hak Atas Tanah.

Ketentuan Pasal 8 Peraturan Presiden Republik Indonesia Nomor 99 Tahun 2014 Tentang Perubahan Kedua Atas Peraturan Presiden Nomor 71 Tahun 2012 Tentang Penyelenggaraan Pengadaan Tanah Bagi Pembangunan Untuk Kepentingan Umum, Guna kepentingan Proyek Pembangunan jalan lingkar luar dibentuklah panitia pengadaan tanah yang terdiri dari unsur Pemerintah Kota, unsur Dinas Pekerjaan Umum (sekarang Dinas Pemukiman dan Prasarana Wilayah) Kota Kendari, unsur Dinas Pertanian (sekarang Dinas

5 Panitia Pengadaan Tanah, Wawancara tanggal 10 Oktober 2018. 
Pertanian dan Tanaman Pangan) Kota Kendari, unsur dari Kantor Pelayanan Pajak Bumi dan Bangunan Kota Kendari, serta unsur Kantor Pertanahan Kota Kendari. Sebagai Ketua, Walikota Kendari; Kepala Kantor Pertanahan Kota Kendari, sebagai Wakil ketua; Kantor Pelayanan Pajak Bumi dan Bangunan Kota Kendari, sebagai anggota; Kepala Dinas Pekerjaan Umum Kota Kendari; sebagai anggota; Kepala Dinas Pertanian Kota Kendari, sebagai anggota; Camat Puuwatu, Camat Baruga, sebagai anggota; serta para Lurah yang terkena proyek jalan lingkar luar, sebagai anggota; dan Kepala Bagian Perlengkapan pada Sekretariat Daerah Kota Kendari, sebagai Sekretaris.

Sebagai langkah selanjutnya dalam Proyek Pembangunan jalan lingkar luar dilakukan upaya Sosialisasi kepada masyarakat yang berdiam di sekitar lokasi jalan lingkar yang direncanakan, yang melibatkan unsur dari Pemerintah Kota Kendari dalam hal ini Walikota, Camat yang wilayahnya dilalui proyek tersebut, Lurah, beserta instansi terkait seperti Kantor Pertanahan Kota Kendari, Kantor Pelayanan Pajak Bumi dan Bangunan Kota Kendari, Dinas Pekerjaan Umum Kota Kendari, dan Dinas Pertanian Kota Kendari, serta dengan melibatkan beberapa Tokoh adat sebagai mediator. Bentuk sosialisasi dilakukan dengan mengumpulkan warga masyarakat yang tanahnya terkena Proyek lingkar jalan di Kecamatan Baruga untuk bermusyawarah mengenai pentingnya Proyek Pembangunan jalan lingkar luar tersebut, sekaligus membicarakan mengenai pelepasan atau pembebasan Hak Atas Tanah yang dimiliki warga sekitar dengan kompensasi bentuk ganti kerugian berupa uang, relokasi, dan atau uang dan relokasi, serta memusyawarahkan besarnya ganti kerugian yang diinginkan oleh masyarakat.

Sosialisasi tersebut dilakukan sekitar enam sampai dengan sembilan bulan sebelum dilaksanakannya Proyek Pembangunan jalan lingkar oleh Pemerintah Kota Kendari melalui tokoh adat sebagai mediator. Setelah dilakukan sosialisasi, selanjutnya dilakukan upaya Musyawarah sebagaimana yang diamanatkan oleh Presiden Republik Indonesia Nomor 99 Tahun 2014 Tentang Perubahan Kedua Atas Peraturan Presiden Nomor 71 Tahun 2012 Tentang Penyelenggaraan Pengadaan Tanah Bagi Pembangunan untuk Kepentingan Umum bahwa: "pengadaan tanah bagi pelaksanaan pembangunan untuk kepentingan umum dilakukan melalui musyawarah." Musyawarah tersebut dilakukan sebanyak 2 kali, bertempat di Kantor kecamatan Baruga, dalam bentuk pertemuan antara 
Pemerintah Kota Kendari dengan warga masyarakat yang tanahnya akan terkena Proyek Pembangunan jalan lingkar luar. ${ }^{6}$

Dalam musyawarah tersebut Warga masyarakat menyambut baik akan dilaksanakannya Proyek Pembangunan jalan lingkar luar dengan kesediaan mereka untuk melepaskan Hak Atas Tanah mereka, asalkan ganti kerugian yang diterima dianggap pantas atau memadai. Untuk membahas mengenai besar dan bentuk ganti kerugian, dilakukan beberapa kali musyawarah dengan warga masyarakat yang tujuan utamanya adalah untuk membicarakan mengenai besaran dan bentuk ganti kerugian.

Sampai dengan bulan Desember 2014, dari 360 pemilik/pemegang Hak Atas Tanah, terdapat 27 pemilik/pemegang Hak Atas Tanah dan semuanya pemilik tanah adat yang belum mau melepaskan hak atas tanahnya untuk Proyek Pembangunan jalan lingkar luar tersebut, karena menganggap belum pantas dan memadainya harga ganti kerugian yang diberikan oleh Pemerintah Kota Kendari. ${ }^{7}$

Terhadap 27 orang pemilik/pemegang Hak Atas Tanah adat yang belum menerima ganti kerugian ini, menurut Pasal 73 Peraturan Presiden Republik Indonesia Nomor 99 tahun 2014 tentang perubahan kedua atas Peraturan presiden nomor 71 tahun 2012 tentang penyelenggaraan pengadaan tanah bagi pembangunan untuk kepentingan umum, yang menyatakan:

1. Dalam hal tidak terjadi kesepakatan mengenai bentuk dan/atau besarnya Ganti Kerugian, Pihak yang Berhak dapat mengajukan keberatan kepada Pengadilan Negeri setempat dalam waktu paling lama 14 (empat belas) hari kerja setelah ditandatangani Berita Acara hasil musyawarah sebagaimana dimaksud dalam Pasal 72 ayat (3).

2. Pengadilan Negeri memutus bentuk dan/atau besarnya Ganti Kerugian dalam waktu paling lama 30 (tiga puluh) hari kerja sejak diterimanya pengajuan keberatan.

3. Pihak yang keberatan terhadap putusan Pengadilan Negeri sebagaimana dimaksud pada ayat (2) dalam waktu paling lama 14 (empat belas) hari kerja dapat mengajukan kasasi kepada Mahkamah Agung.

\footnotetext{
6 Gabi, pemilik/pemegang hak atas tanah yang telah melepaskan hak atas tanahnya untuk proyek pembangunan jalan lingkar luar. Wawancara tanggal 7 Oktober 2018.

7 Data Pengadaan Tanah Kota Kendari Tahun Anggaran 2014.
} 
4. Mahkamah Agung wajib memberikan putusan dalam waktu paling lama 30 (tiga puluh) hari kerja sejak permohonan kasasi diterima.

Lebih lanjut menurut Pasal 86 Peraturan Presiden Republik Indonesia Nomor 99 tahun 2014 tentang perubahan kedua atas Peraturan presiden nomor 71 tahun 2012 tentang penyelenggaraan pengadaan tanah bagi pembangunan untuk kepentingan umum dalam hal pemilik hak menolak untuk menerima ganti rugi dan tidak mengajukan di pengadilan maka instansi yang memerlukan tanah mengajukan permohonan penitipan Ganti Kerugian kepada ketua pengadilan negeri pada wilayah lokasi pembangunan untuk Kepentingan Umum.

Apa yang dinyatakan dalam kedua pasal Peraturan Presiden Republik Indonesia Nomor 99 tahun 2014 tentang perubahan kedua atas Peraturan presiden nomor 71 tahun 2012 tentang penyelenggaraan pengadaan tanah bagi pembangunan untuk kepentingan umum tersebut di atas tidak dilaksanakan atau ditempuh, baik oleh pemilik/pemegang Hak Atas Tanah maupun oleh Pemerintah Kota Kendari. ${ }^{8}$ Bagi Pemerintah Kota Kendari sendiri, terhadap pemilik/pemegang Hak Atas Tanah masih dilakukan musyawarah, untuk mencapai kesepakatan mengenai besarnya ganti kerugian. Dengan melakukan pendekatan secara kekeluargaan, hal ini disebabkan karena sifat kekeluargaan tersebut melekat erat dalam setiap sisi kehidupan masyarakat di Kota Kendari. ${ }^{9}$

\section{Prinsip Penghormatan Terhadap Hak Tanah Adat dalam Pemberian Ganti Kerugian pada Proyek Pembangunan Jalan Lingkar Luar (Outer Ring Road) di Kota Kendari}

Pelaksanaan pengadaan tanah untuk menjamin terselenggaranya pembangunan untuk kepentingan umum, diperlukan tanah yang pengadaannya dilaksanakan dengan mengedepankan prinsip kemanusiaan, demokratis, dan adil, demikian amanah UndangUndang Nomor 2 Tahun 2012 bagian (b) konsiderans menimbangnya. Implementasi pengadaannya tanah untuk kepentingan umum dengan mengedepankan prinsip kemanusiaan, demokratis, dan adil, dapat ditemukan dalam beberapa Keputusan Presiden maupun perubahannya, antara lain:

1. Keputusan Presiden Nomor 55 Tahun 1993 dalam konsiderans menimbang bahwa Pelaksanaan pengadaan tanah dilakukan dengan memerhatikan peran

8 Pemilik/pemegang hak atas tanah yang telah melepaskan hak atas tanahnya untuk proyek pembangunan jalan lingkar luar. Wawancara tanggal 7 Oktober 2018.

9 Askar Mahmud, Kepala Badan Perencanaan Pembangunan Daerah Kota Kendari. Wawancara tanggal 8 Oktober 2018. 
tanah dalam kehidupan manusia dan prinsip penghormatan terhadap hak-hak yang sah atas tanah., Lebih lanjut penghormatan terhadap hak atas tanah termasuk tanah adat tersebut juga ditegaskan dalam Pasal 3 Keputusan Presiden Nomor 55 Tahun 1993 yang berbunyi: Meningkatnya pembangunan untuk kepentingan umum yang memerlukan tanah, maka pengadaannya perlu dilakukan secara cepat dan transparan dengan tetap memerhatikan prinsip penghormatan terhadap hak-hak yang sah atas tanah.

2. Peraturan Presiden Nomor 36 tahun 2005 tentang Pengadaan Tanah Bagi Pelaksanaan Pembangunan Untuk Kepentingan Umum. Selain dalam konsideransnya tetap menyebutkan penghormatan terhadap hak atas tanah termasuk tanah adat, Pada Pasal 3 ayat (1) Peraturan Presiden Nomor 36 tahun 2005 dinyatakan bahwa pelepasan atau penyerahan hak atas tanah dilakukan berdasarkan prinsip penghormatan terhadap hak atas tanah.

3. Peraturan Presiden Nomor 65 Tahun 2006 Tentang Perubahan Atas Peraturan Presiden Nomor 36 Tahun 2005 Tentang Pengadaan Tanah Bagi Pelaksanaan Pembangunan untuk Kepentingan Umum, yang mulai diberlakukan tanggal 5 Juni 2006 mengubah ketentuan Pasal 3 ayat (1) Peraturan Presiden Nomor 36 tahun 2005, menjadi Pasal 3 baru yang berbunyi: "Pelepasan atau penyerahan hak atas tanah sebagaimana dimaksud dalam Pasal 2 dilakukan berdasarkan prinsip penghormatan terhadap hak atas tanah.

4. Peraturan Presiden Republik Indonesia Nomor 71 Tahun 2012 Tentang Penyelenggaraan Pengadaan Tanah Bagi Pembangunan Untuk Kepentingan Umum. Walaupun dalam konsiderans peraturan presiden tersebut tidak menyebutkan Prinsip penghormatan terhadap hak atas tanah termasuk tanah adat, tetapi prinsip penghormatan terhadap hak atas tanah secara tersirat diatur dalam pasal 1 bagian b Peraturan Presiden Republik Indonesia Nomor 71 Tahun 2012 Bahwa Pengadaan Tanah adalah kegiatan menyediakan tanah dengan cara memberi Ganti Kerugian yang layak dan adil kepada Pihak yang Berhak.

Kebijakan pemerintah mengenai pengadaan tanah bagi pelaksanaan pembangunan untuk kepentingan umum, semuanya mengarah pada prinsip penghormatan terhadap hak atas tanah termasuk tanah adat. secara mutlak ini harus diperhatikan dan dilaksanakan oleh pemerintah, agar tidak menimbulkan rasa sakit kepada pemilik/pemegang Hak Atas 
Tanah yang menyerahkan atau melepaskan hak atas tanahnya dalam pelaksanaan pembangunan untuk kepentingan umum. walaupun dilaksanakan oleh pemerintah yang mewakili negara dalam penerapan konsep hak menguasai negara atas tanah yang menjadikan negara sebagai pengatur peruntukan, pemeliharaan, pemberian hak atas tanah dan sebagainya, yang merupakan amanat dari Pasal 33 ayat (3) Undang-Undang Dasar 1945, dimaksudkan bahwa hak menguasai negara tersebut harus dapat memberikan kemakmuran kepada seluruh rakyat Indonesia.

Pada Proyek pembangunan jalan lingkar luar (outer ring road) di Kota Kendari, pemerintah melakukan tahapan-tahapan sebagaimana yang ditentukan dalam berbagai kebijakan pemerintah yang berkaitan dengan pengadaan tanah bagi pelaksanaan pembangunan untuk kepentingan umum. Dimulai dari tahap pembentukan Panitia Pengadaan Tanah, sosialisasi, musyawarah, sampai pada pelaksanaan pemberian ganti kerugian. Menurut keterangan yang diperoleh penulis berdasarkan wawancara dengan salah satu orang pemilik/pemegang Hak Atas Tanah adat di Kelurahan Abeli Dalam yang belum mau melepaskan atau menyerahkan hak atas tanahnya adatnya, bahwa Pemerintah Kota Kendari sampai sekarang tidak pernah melakukan upaya intimidasi, menakut-nakuti, atau memberi tekanan (pressure) kepadanya. Hal ini berbeda dengan pengadaan tanah bagi pelaksanaan pembangunan untuk kepentingan umum yang terjadi di tempat lain di Indonesia, yang sering kita dengar atau diterima informasinya melalui media massa atau dalam beberapa tulisan, bahwa pengadaan tanah bagi pelaksanaan pembangunan untuk kepentingan umum sarat dengan intimidasi ataupun tekanan dari pihak yang memerlukan tanah kepada pihak yang enggan atau belum mau untuk melepaskan atau menyerahkan hak atas tanahnya.

Prinsip penghormatan terhadap tanah adat tercermin juga dalam penetapan dan pemberian ganti rugi terhadap pemilik tanah adat. Pada pengadaan tanah untuk Proyek Pembangunan Jalan lingkar luar ini, Pemerintah Kota Kendari berupaya agar rasa keadilan bagi pemilik/pemegang Hak Atas Tanah dapat terpenuhi. Perbedaan nilai ganti rugi yang diberikan kepada pemilik hak atas tanah bukan didasarkan kepada perbedaan hak atas tanah tetapi lebih pada perbedaan luas tanah yang dibebaskan, di samping itu pemerintah lebih memberikan pertimbangan lain kepada hak atas tanah yang dipunyai oleh warga masyarakat sebagai tempat untuk menjalankan usaha pemenuhan kebutuhan hidup sehari-hari sehingga orang yang menyerahkan tanahnya tidak kehilangan pendapatan selanjutnya dapat digunakan untuk membiayai sekolah anak-anak mereka, atau dapat 
mereka gunakan untuk modal usaha, di samping itu mereka juga dapat menempati rumah baru yang kondisinya lebih baik dari rumah mereka dahulu.

Berdasarkan pelaksanaan pengadaan tanah untuk kepentingan umum dalam proyek jalan lingkar luar di Kota Kendari dan prinsip-prinsip penghormatan terhadap hak atas tanah termasuk tanah adat dalam berbagai peraturan tersebut di atas maka di Kota Kendari penghormatan sekaligus pengakuan keberadaan tanah adat telah sesuai dengan amanah UUD 1945 pasal 18 b, walaupun pengakuannya dengan syarat sepanjang subyeknya, hukumnya dan obyeknya kenyataannya masih ada dan tidak bertentangan dengan negara kesatuan Republik Indonesia. Pasal 3 UU No. 5 Tahun 1960 tentang Peraturan Dasar Pokok-Pokok Agraria (UUPA) menentukan bahwa:10

Pelaksanaan hak ulayat dan hak-hak yang serupa itu dari masyarakat-masyarakat hukum adat, sepanjang menurut kenyataannya masih ada, harus sedemikian rupa sehingga sesuai dengan kepentingan nasional dan negara, yang berdasarkan persatuan bangsa serta tidak boleh bertentangan dengan undang-undang dan peraturan-peraturan yang lebih tinggi.

Pasal 3 UUPA di atas, mengakui berlakunya hak-hak ulayat maupun hak-hak adat lain dengan persyaratan: a) hak ulayat atau hak-hak adat lainnya (tanah adat Individu) masih terdapat dalam masyarakat (masih merupakan kenyataan hidup); b)Sesuai dengan kepentingan nasional/negara; c) Tidak bertentangan dengan undang-undang dan peraturan lain. ${ }^{11}$

Demikian pula Pasal 22 Peraturan Presiden Republik Indonesia Nomor 71 Tahun 2012 Tentang Penyelenggaraan Pengadaan Tanah Bagi Pembangunan Untuk Kepentingan Umum. Menetapkan syarat subyek hukum tanah adat yaitu terdapat sekelompok orang yang masih menggunakan hukum adatnya, obyeknya, lembaga adatnya dan diakui melalui peraturan daerah. ${ }^{12}$

Terkait syarat pengakuan tanah adat tersebut di atas, Menurut Bahar ${ }^{13}$ mempunyai kelemahan dari aspek logika dan politik. Dari segi logika menurutnya tidak mungkin suatu masyarakat hukum adat yang dibangun berdasarkan hubungan genealogis dan teritorial

10 Winahyu Erwiningsih, Hak Menguasai Negara Atas Tanah, Yogyakarta: Total Media, 2009, hlm. 4. Lihat juga Pasal 3 Undang-Undang Nomor 5 Tahun 1960 tentang Peraturan Dasar Pokok-Pokok Agraria (Lembaran Negara Republik Indonesia Tahun 1960 Nomor 104, Tambahan Lembaran Negara Republik Indonesia Nomor 2043).

11 Ibid., hlm. 5.

12 Pasal 22 ayat (1) dan (2) Peraturan Presiden Republik Indonesia Nomor 71 Tahun 2012 Tentang Penyelenggaraan Pengadaan Tanah Bagi Pembangunan Untuk Kepentingan Umum.

13 S. Bahar, Inventarisasi dan Perlindungan Hak Masyarakat Hukum Adat, Jakarta: Komisi Nasional Hak Asasi Manusia, 2005, hlm. 8. 
bisa menjadi tidak ada kecuali kalau musnah karena bencana alam yang sangat dahsyat atau terjadinya genosida. Jika hal seperti itu terjadi maka negara berkewajiban melindungi agar masyarakatnya tidak musnah. Dari segi politik pernyataan "sesuai dengan kepentingan nasional dan negara, yang berdasarkan atas persatuan bangsa" merupakan suatu a priori yang mengandung kecurigaan dari pemerintah terhadap masyarakat hukum adat. Pernyataan ini menunjukkan seolah-olah masyarakat hukum adat itu bukan merupakan bagian kenasionalan, kenegaraan dan kebangsaan. Bukankah pemenuhan kepentingan masyarakat hukum adat itu merupakan bagian upaya pemenuhan kepentingan nasional?.14

Selanjutnya menurut Bahar ${ }^{15}$ terkait persyaratan "tidak boleh bertentangan dengan peraturan yang lebih tinggi" sebagaimana disebutkan di atas, hak atas tanah adat secara konstitusional juga di akui melalui Pasal 18B ayat (2) Undang-Undang Dasar Negara Kesatuan Republik Indonesia 1945 (UUD NRI Tahun 1945).

\section{KESIMPULAN}

1. Pengadaan tanah untuk kepentingan umum di Kota Kendari dilaksanakan dengan cara penghormatan dan pengakuan tanah adat yaitu melalui beberapa kali dilaksanakan musyawarah untuk menyepakati besarnya ganti rugi yang diterima para pemilik tanah adat. selain itu pemerintah dapat saja menerapkan Pasal 86 Peraturan Presiden Republik Indonesia Nomor 99 Tahun 2014 Tentang Perubahan Kedua Atas Peraturan Presiden Nomor 71 Tahun 2012 Tentang Penyelenggaraan Pengadaan Tanah Bagi Pembangunan Untuk Kepentingan Umum dalam hal pemilik hak menolak untuk menerima ganti rugi dan tidak mengajukan di pengadilan maka instansi yang memerlukan tanah mengajukan permohonan penitipan Ganti Kerugian kepada ketua pengadilan negeri pada wilayah lokasi pembangunan untuk Kepentingan Umum. Prinsip penghormatan terhadap tanah adat tercermin juga dalam penetapan dan pemberian ganti rugi terhadap pemilik tanah adat yaitu Perbedaan nilai ganti rugi yang diberikan kepada pemilik hak atas tanah bukan didasarkan kepada perbedaan hak atas tanah tetapi lebih pada perbedaan luas tanah yang dibebaskan, di samping itu pemerintah lebih memberikan pertimbangan lain 
kepada hak atas tanah yang dipunyai oleh warga masyarakat sebagai tempat untuk menjalankan usaha pemenuhan kebutuhan hidup sehari-hari sehingga orang yang menyerahkan tanahnya tidak kehilangan pendapatan.

2. Implementasi pengadaannya tanah untuk kepentingan umum dengan mengedepankan prinsip kemanusiaan, demokratis, dan adil, dapat ditemukan dalam beberapa Keputusan Presiden maupun perubahannya, yaitu: Keputusan Presiden Nomor 55 Tahun 1993 dalam konsiderans menimbang bahwa Pelaksanaan pengadaan tanah dilakukan dengan memerhatikan peran tanah dalam kehidupan manusia dan prinsip penghormatan terhadap hak-hak yang sah atas tanah. Lebih lanjut penghormatan terhadap hak atas tanah termasuk tanah adat tersebut juga ditegaskan dalam Pasal 3 Keputusan Presiden Nomor 55 Tahun 1993 yang berbunyi: Meningkatnya pembangunan untuk kepentingan umum yang memerlukan tanah, maka pengadaannya perlu dilakukan secara cepat dan transparan dengan tetap memerhatikan prinsip penghormatan terhadap hak-hak yang sah atas tanah. Peraturan Presiden Nomor 36 tahun 2005 tentang Pengadaan Tanah Bagi Pelaksanaan Pembangunan Untuk Kepentingan Umum. Selain dalam konsideransnya tetap menyebutkan penghormatan terhadap hak atas tanah termasuk tanah adat, Pada Pasal 3 ayat (1) Peraturan Presiden Nomor 36 Tahun 2005 dinyatakan bahwa pelepasan atau penyerahan hak atas tanah dilakukan berdasarkan prinsip penghormatan terhadap hak atas tanah. Peraturan Presiden Nomor 65 Tahun 2006 Tentang Perubahan Atas Peraturan Presiden Nomor 36 Tahun 2005 Tentang Pengadaan Tanah Bagi Pelaksanaan Pembangunan untuk Kepentingan Umum, yang mulai diberlakukan tanggal 5 Juni 2006 mengubah ketentuan Pasal 3 ayat (1) Peraturan Presiden Nomor 36 tahun 2005, menjadi Pasal 3 baru yang berbunyi: "Pelepasan atau penyerahan hak atas tanah sebagaimana dimaksud dalam Pasal 2 dilakukan berdasarkan prinsip penghormatan terhadap hak atas tanah. Peraturan Presiden Republik Indonesia Nomor 71 Tahun 2012 Tentang Penyelenggaraan Pengadaan Tanah Bagi Pembangunan Untuk Kepentingan Umum. Walaupun dalam konsiderans peraturan presiden tersebut tidak menyebutkan Prinsip penghormatan terhadap hak atas tanah termasuk tanah adat, tetapi prinsip penghormatan terhadap hak atas tanah secara tersirat diatur dalam pasal 1 bagian b Peraturan 
Presiden Republik Indonesia Nomor 71 Tahun 2012 bahwa Pengadaan Tanah adalah kegiatan menyediakan tanah dengan cara memberi Ganti Kerugian yang layak dan adil kepada Pihak yang Berhak.

\section{Daftar Pustaka}

\section{Buku}

Oprasi, Agus, Pelaksanaan Pemberian Ganti Kerugian Terhadap Hak Atas Tanah Yang Terkena Proyek Pembangunan Water Front City di Kabupaten Sambas, Provinsi Kalimantan Barat, Tesis, Semarang: Universitas Diponegoro, 2009.

Erwiningsih, Winahyu, Hak Menguasai Negara Atas Tanah, Yogyakarta: Total Media, 2009. Bahar, S., Inventarisasi dan Perlindungan Hak Masyarakat Hukum Adat, Jakarta: Komisi Nasional Hak Asasi Manusia, 2005.

\section{Peraturan Perundang-undangan}

Undang-Undang Dasar Negara Republik Indonesia Tahun 1945.

Undang-Undang Nomor 5 Tahun 1960 tentang Peraturan Dasar Pokok-Pokok Agraria (Lembaran Negara Republik Indonesia Tahun 1960 Nomor 104, Tambahan Lembaran Negara Republik Indonesia Nomor 2043).

Undang-Undang Republik Indonesia Nomor 2 Tahun 2012 tentang Pengadaan Tanah Bagi

Pembangunan untuk Kepentingan Umum (Lembaran Negara Republik Indonesia Tahun 2012 Nomor 22, Tambahan Lembaran Negara Republik Indonesia Nomor 5280).

Keputusan Presiden Republik Indonesia Nomor 55 Tahun 1993 Tentang Pengadaan Tanah Bagi Pelaksanaan Pembangunan untuk Kepentingan Umum.

Peraturan Presiden Nomor 36 Tahun 2005 tentang Pengadaan Tanah Bagi Pelaksanaan Pembangunan Untuk Kepentingan Umum.

Peraturan Presiden Nomor 65 Tahun 2006 Tentang Perubahan Atas Peraturan Presiden Nomor 36 Tahun 2005 Tentang Pengadaan Tanah Bagi Pelaksanaan Pembangunan Untuk Kepentingan Umum.

Peraturan Presiden Republik Indonesia Nomor 71 Tahun 2012 Tentang Penyelenggaraan Pengadaan Tanah Bagi Pembangunan Untuk Kepentingan Umum. 